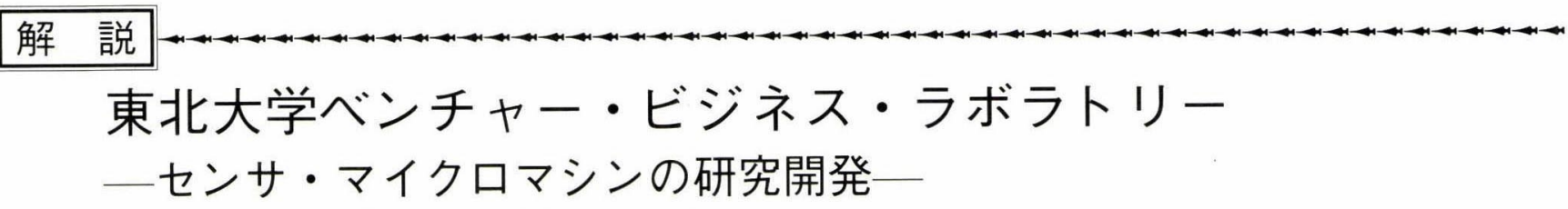

Venture Business Laboratory Tohoku University

- Development of Sensors and Micromachines-

江 刺 正 喜* *東北大学未来科学技術共同研究センター Masayoshi Esashi* ${ }^{*}$ New Industry Creation Hatchery Center Tohoku University

1. 経

緯

「東北大学ベンチャー・ビジネス・ラボラトリー」(ラボ ラトリー長 羽根一博教授) は「センサ・マイクロマシンの 研究開発」をテーマに平成 7(1995) 年度にスタートした。 全学的に利用され（現在の登録利用者は約 300 名）, 多く の成果を上げてきた。本格的なセンサ・マイクロマシンの 試作研究開発が行える環境を提供しており, 共同研究など 多様な形で企業など学外のかたにも利用していただいてい る。近くのナノマシニング棟や他の設備も含めて, 主に半 導体技術を基本にした「マイクロマシニング」や, 走査プ ローブ顕微鏡などの技術を用いた「ナノマシニング」に共 同利用されており，2 インチウェハ用と $20[\mathrm{~mm}]$ 角ウェハ 用の 2 系統の試作ラインにより, 高集積度と多自由度を使 い分けている．異種分野の技術を融合してさまざまな分野 に応用するため，オープンにして知識の交流を盛んにして いる.

な扮平成 10 （1998）年度より産業支援の役割を担う「東 北大学末来科学技術共同研究センター (New Industry Creation Hatchery Center (NICHe) )」がスタートした、筆 者はその中で「省エネルギ省資源工学」を担当している，以 下ではこのようななかで進めている研究の概要を紹介する.

\section{2. マイクロマシニング}

フォトリソグラフィでマスクパターンを一括転写するこ とで複雑なシステムを小さく作ることができ，またエッチ ングなどによって立体的に加工することで，回路だけでな くセンサやアクチュエータなどシステムのすべての要素を 小形一体化することができる.ドライエッチングの一つで， 表面からフッ素などの反応性イオンを照射し深く加工する 反応性イオンエッチング (Deep RIE) が用いられる。図 1 (a) はシリコン振動ジャイロの製作途中の例であるが， Si をDeep RIEした後酸化して側面を $\mathrm{SiO}_{2}$ で覆い, $\mathrm{XeF}_{2}$

原稿受付 2000 年 5 月 1 日

キーワード : Sensor, Micromachine, Microactuator, Micromachining, Micro Probe

$*$ ₹ 980-8579 仙台市青葉区荒巻字青葉 01

*Aoba-ku, Sendai-shi, Miyagi

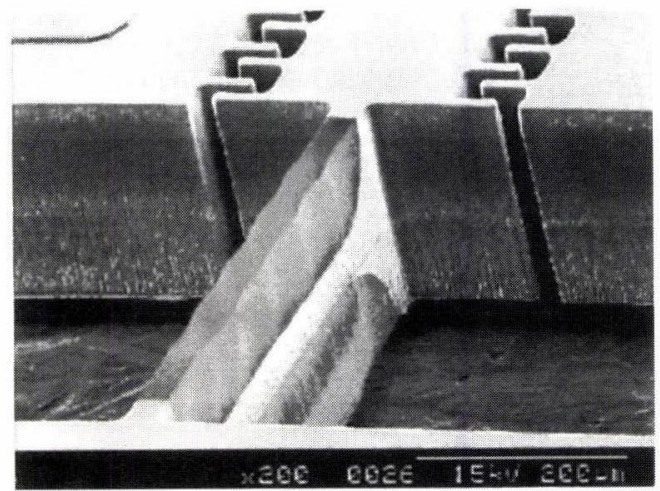

(a) Si の Deep RIE 後側面を酸化し, 上下から $\mathrm{Si}$ ¿ XeF2 ガスエッチングした例

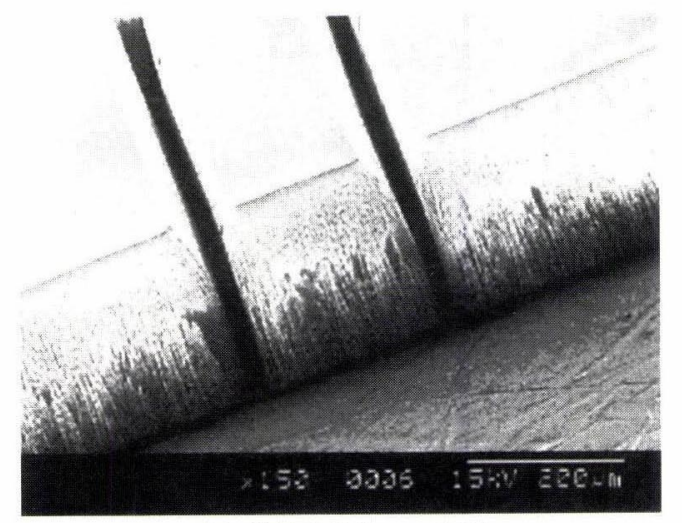

(b) ガラスの Deep RIE

図 1 Deep RIE

ガス中で上下から $\mathrm{Si}$ をエッチングしてある. $\mathrm{SiO}_{2}$ を除去 すれば，幅と厚さを独立に制御した立体構造体ができる $[1]$. 各種の Deep RIE 装置を製作しており，エッチングしにく い材料でも垂直に深くエッチングしている．図 1 (b) は厚 さ $200[\mu \mathrm{m}]$ のパイレックスガラスを $20[\mu \mathrm{m}]$ 幅でエッチン グしてある $[2]$.このほか, 水晶や $\mathrm{SiC}, \mathrm{PZT}$ などの Deep RIE 技術を開発している.

マイクロアクチュエータなどに役立つ各種の機能性材料 を微細加工するため, Deep RIEで微細加工した Si を鋳 型にして燒結することで PZT や $\mathrm{SiC}$ のようなセラミック スの微細構造体を製作して扔り，図 2 は耐熱性材料である 
(1) Deep RIE による $\mathrm{Si}$ 鋳型の作成

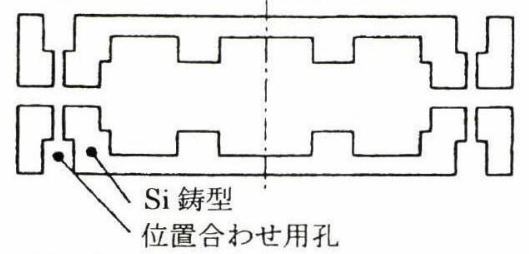

(2) 材料粉末の充填と貼り合わせ

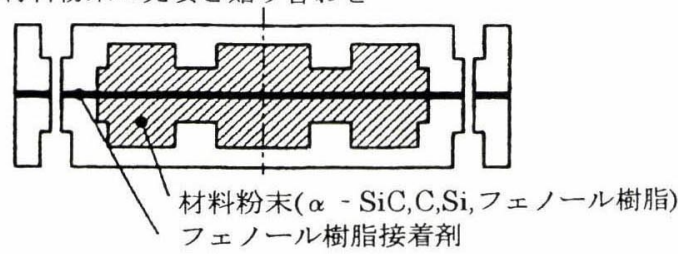

(3) ガラス封入と反応燒結 $\left(1700^{\circ} \mathrm{C}, 50 \mathrm{Mpa}\right)$

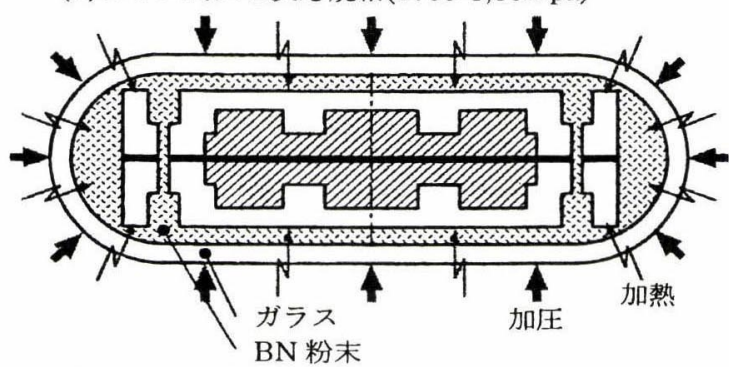

(4) サンプル取出し

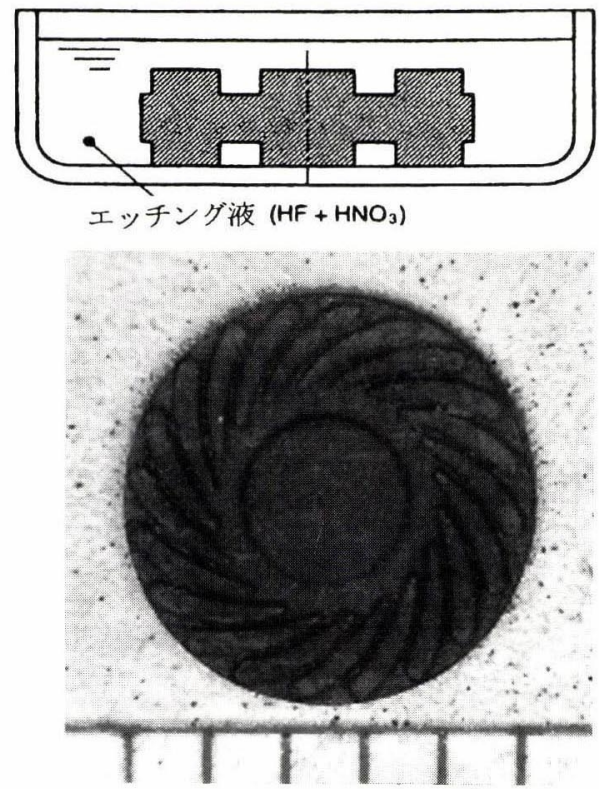

図 $2 \mathrm{SiC}$ のシリコンローストモールド反応燒結法と作製した マイクロタービンブレード

$\mathrm{SiC}$ の例である [3]．材料粉末を $\mathrm{Si}$ の鋳型に入れて等方的 に加圧しながら燒結するが，その温度は Si の融点以上なの で融解した Si も反応に寄与する。最後に Si をエッチング して試料を取り出す。
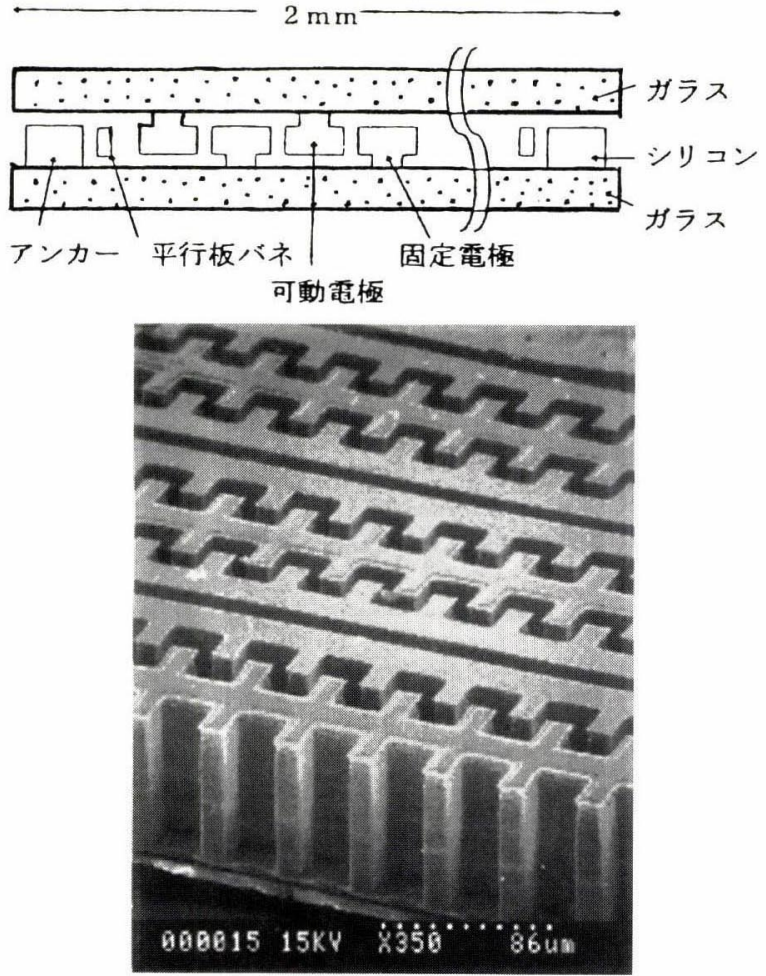

図 3 分布型静電マイクロアクチュエータ

\section{3. マイクロアクチュエータ}

図 3 はハードディスクのヘッドに取り付けて，トラッキ ング制御に用いる分布型静電マイクロアクチュエータであ る [4]. Si の Deep RIEで電極間隔 $5[\mu \mathrm{m}]$ 深さ $100[\mu \mathrm{m}]$ に 加工した静電マイクロアクチュエータが多数並列に作られ ており，大きな力を発生する。

静電アクチュエータで大きな力を発生するには，電極間 隔が狭くても放電せずに大きな電圧を印加できる必要があ る。このため狭い間隔での放電に関する研究を行い，電極 に金属でなくSi を使えば，気圧と電極間隔に対する放電電 圧の関係であるパッシェン曲線で決まる放電開始電圧まで 放電せずに電圧を印加できることを明らかにした [5].

積層圧電アクチュエータは比較的小さな電圧で大きな力 を発生できるので多く使われている。これを多数配列させ た構造にするため，平面的に製作する方法を開発した [6]. 図 4 にその方法を示す.PZT 板に溝を入れてその間をめっ きによる金属で埋め，その後レーザ支援エッチングによっ て不要な部分を切断する方法である，特性は従来と同等で あるが，多数のアクチュエータが平面的に分布した触覚ディ スプレイ装置などに応用できる。

図 5 はSiの Deep RIEによって製作したエアタービン である [7]. 軸受け用の空気も導入することで 1 万 $[\mathrm{rpm}]$ 程 で回転させている。これの回転子には赤外線用のグリッド 
$\mathrm{PZT}$ 基板(厚さ $500 \mu \mathrm{m}$ )

ダイシング(幅 $30 \mu \mathrm{m}$ 深さ $100 \mu \mathrm{m}$ )

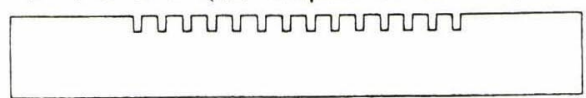

めっき下地層 $(\mathrm{Au} / \mathrm{Cr})$ スパッタ堆積

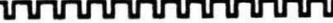

ポリッシング

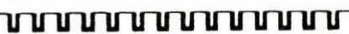

$\mathrm{Ni}$ 電解めつき、ポリッシング

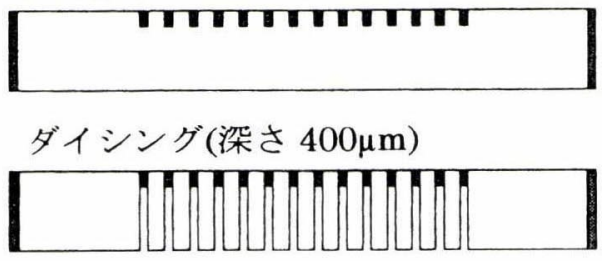

$\mathrm{Ni}$ 電解めつき、ポリッシング

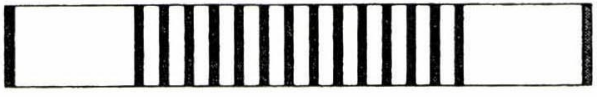

レーザ支援エッチング $\left(3 \mathbf{w t} \% \mathrm{FeCl}_{3}\right)$
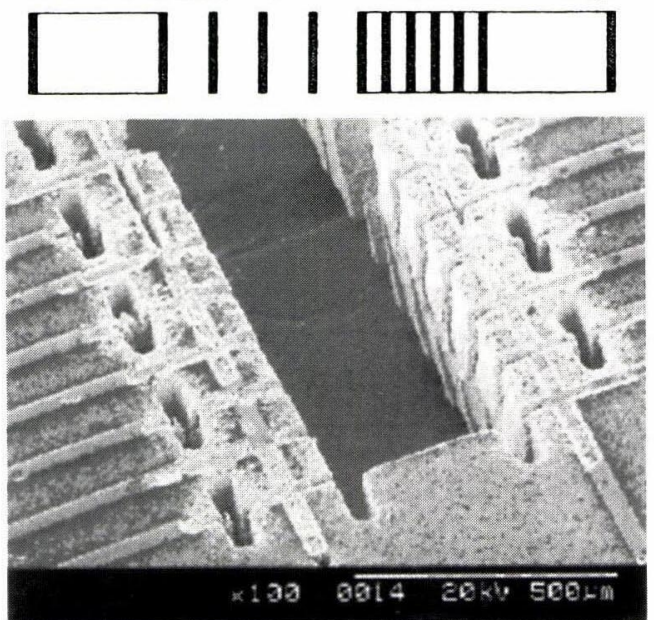

図 4 平面加工による積層压電アクチュエー夕

偏光子が形成されており偏光変調器として使用できる。上 述の $\mathrm{SiC}$ の技術でこれを製作し，携带用電源としての小形 エンジン発電機に応用する計画である.

\section{4. マイクロプローブ}

極端に小形化すると，空間分解能が高いだけでなく，機 械的にも熱的にも高感度・高速応答するセンサなどを実現

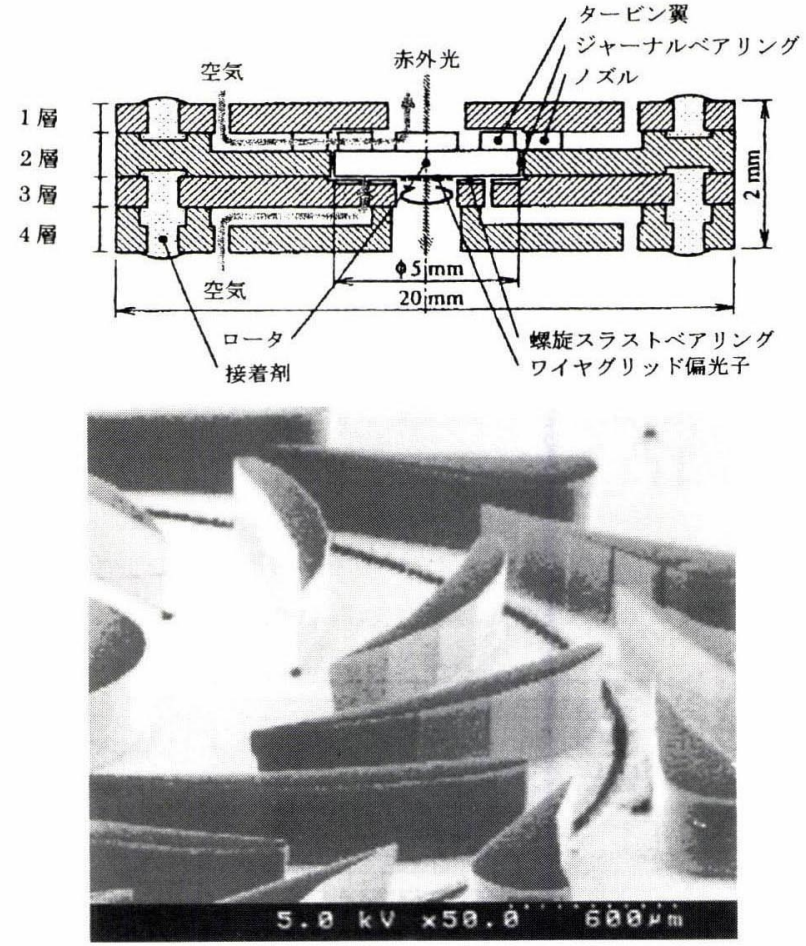

図 5 マイクロエアタービン

することができる $[8]$ ．原子間力顕微鏡（AFM）のプロー ブは，原子間力による薄い片持ち梁のたわみを光の反射で 検出している。図 6 は梁のたわみを静電容量変化で検出す る $\mathrm{AFM}$ プローブである，先端には $20[\mathrm{~nm}]$ 程の開口を形 成してあり近接場光顕微鏡 (SNOM) としても利用できる [9].

薄い振動子の共振を用いると高感度なセンサを実現する ことができる。損失が少なく $\mathrm{Q}$ が高いほど，わずかな共振 周波数の変化を検出したり，また周期的な入力エネルギを蓄 積したりできるためである。このため薄い振動子のエネル ギー損失に関する研究を行っている [10]. 図 7 は $170[\mathrm{~nm}]$ 厚の $\mathrm{Si}$ 片持ち梁について Q を超高真空中で測定した例で ある。眓 7 (a)のように加熱して表面の自然酸化膜を蒸発 させることにより，25万方どの大きな $\mathrm{Q}$ が得られている。 図 7 (b) は表面組成と Q の関係を測定したものであり，こ れからも自然酸化膜により Q が低下することが分かる。

5. パッケージングした機械量センサ

$\mathrm{Si}$ をガラスと陽極接合することで封止された構造の小形 センサを作ることができる。この場合に封止した内部から 電気配線を取り出す必要があるが，これには図 1 (b)で説 明したガラスの Deep RIEなどの技術が利用できる。これ により回路を内蔵した集積化容量型圧力センサや，ダイア フラム型真空センサ, 静電サーボ加速度センサ, 振動ジャ イロなどの機械量センサを実現してきた。図 8 は高精度回 


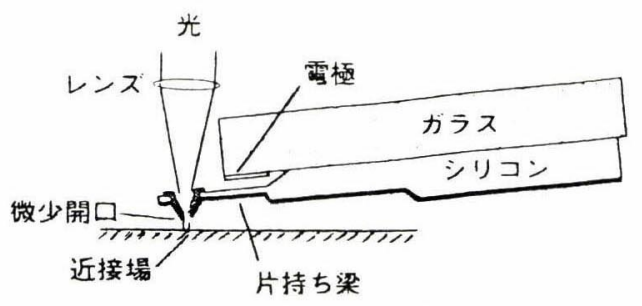

(a) 構造と測定原理

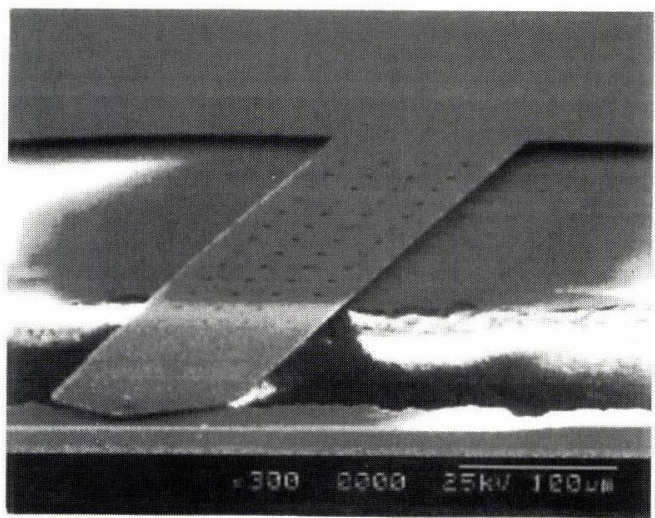

(b) プロープの写真

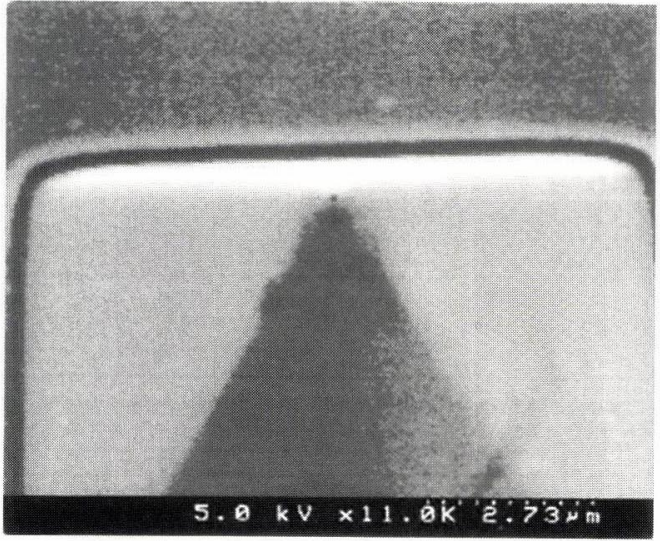

(c) プロープ先端部の写真

図 $6 \mathrm{SNOM} / \mathrm{AFM}$ プローブ

転ジヤイロとして 2 軸まわりの角速度を検出する静電浮上 マイクロモータである。ガラスで封止された真空空洞内で, Deep RIEで製作した Si 円板が静電引力によって浮上する ようになっており, 加速度の 3 方向成分も同時に検出でき る。2,000 [rpm]で回転させることができた [11].

\section{6. そ の 他}

血管内で検査や治療を行うための能動カテーテルや超音 波イメージャなどの関連センサ，耐蝕型集積化マスフロー コントローラなどの微量流体制御システム, DNA チップ などの化学分析システム, 光センサや光部品 [12], 積層型 視覚情報処理 $[13]$ や光インターコネクション, 地熱開発用 の地下マイクロセンサ [14] など幅店い研究を行っている.
- 加熱前

- 加熱 $\left(600^{\circ} \mathrm{C} 30\right.$ 分)後

$\Delta$ さらに加熱 $\left(1000^{\circ} \mathrm{C} 30\right.$ 分)後

- その後 超高真空中に 24 時間放置後

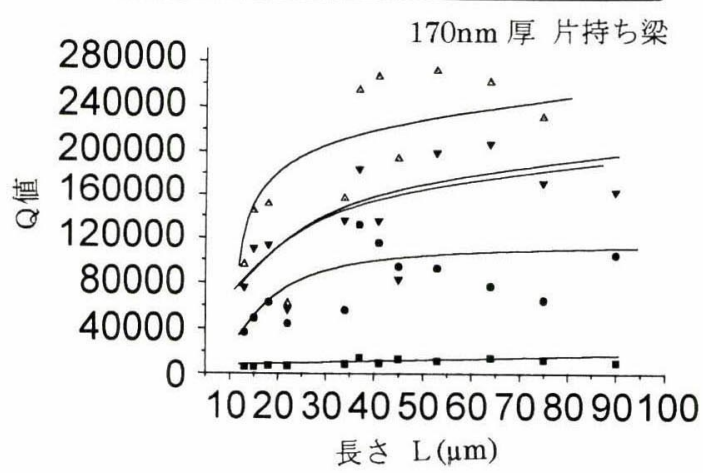

(a) 処理温度と $\mathrm{Q}$ の関係

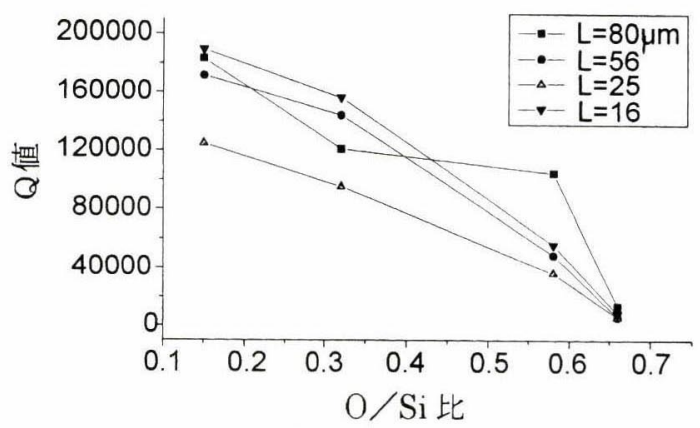

(b) 表面組成と $\mathrm{Q}$ の関係

図 7 マイクロ振動子の特性
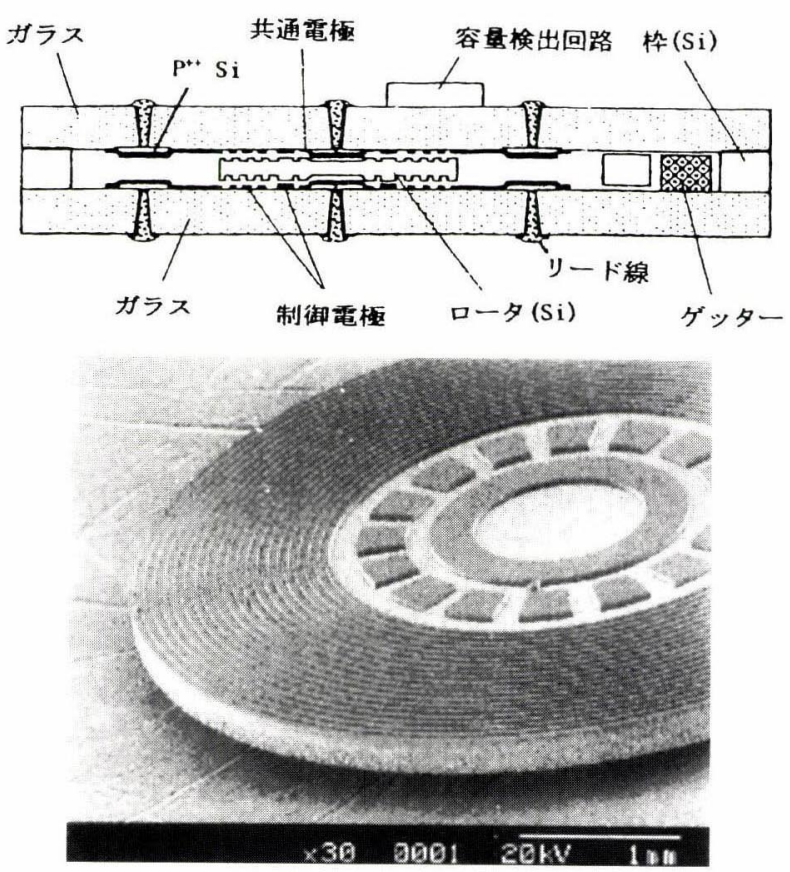

図 8 静電浮上マイクロモー夕 


\section{参 考 文 献}

[1] R. Toda, K. Minami and M. Esashi: "Thin Beam Bulk Micromachining Based on RIE and Xenon Difluoride Silicon Etching," Sensors and Actuators, no.A66, pp.268-217, 1998.

[2] X.Li, T. Abe and M. Esashi: "Deep Reactive Ion Etching of Pyrex Glass," Proc. of the IEEE MEMS'2000, pp.271-276, Miyazaki, Japan, Jan. 23-27, 2000.

[3] S. Sugimoto, S. Tanaka, J.F. Li, R. Watanabe and M. Esashi: "Silicon Carbide Micro-reaction-sintering Using a Multilayer Silicon Mold," Proc. of the IEEE MEMS'2000, pp.775-780, Miyazaki, Japan, Jan. 23-27, 2000.

[4] 阿部宗光, 江刺正喜：“磁気へッド位置合わせ用静電マイクロアクチユ エータの試作”, 第 16 回「センサ・マイクロマシンと応用システム」 シンポジウム和文速報, p. 77, 1998.

[5] T. Ono, D.Y. Sim and M. Esashi: "Imaging of Micro-discharge in a Micro-gap of Electrostatic Actuator," Proc. of the IEEE MEMS'2000, pp.651-656, Miyazaki, Japan, Jan. 23-27, 2000.

[6] G. Suzuki and M. Esashi: "Planer Fabrication of Multilayer Piezoelectric Actuator by Groove Cutting and Electroplating," Proc. of the IEEE MEMS'2000, pp.46-51, Miyazaki, Japan, Jan. 23-27, 2000.

[7] S. Tanaka, M. Hara and M. Esashi: "Air-Turbine-Driven Micro-Polarization Modulator for Fourier Transform Infrared Spectroscopy," Technical Digest of the 17th Sensor Symposium, A1-2, Kawasaki, Japan, May 30-31, 2000.

[8] 江刺正喜：“微小世界の物理学とマイクロマシン”, 日本ロボット学会 誌, vol.14, no.8, pp.1086-1089, 1996.

[9] P.N. Minh, T. Ono and M. Esashi: "Microfabrication of Miniature Aperture at the Apex of $\mathrm{SiO}_{2}$ Tip on Silicon Cantilever for Near-field Scanning Microscopy," Sensors and Actuators, no.80, pp.163-169, 2000.

[10] J. Yang, T. Ono and M. Esashi: "Dominated Energy Dissipation in Ultra Thin Single Crystal Silicon Cantilever: Surface Loss," Proc. of the IEEE MEMS'2000, pp.235-240, Miyazaki, Japan, Jan. 23-27, 2000.

[11] K. Fukatsu, T. Murakoshi and M. Esashi: "Electro-statically Levitated Micro Motor for Inertia Measurement System," Technical Digest of the Transducers'99, pp.1558-1561, Sendai, Japan, June 7-10, 1999.

[12] 羽根一博, 佐々木実: “マイクロマシニングによるメカトロニクス用フォト ダイオードの開発”, 電気学会論文誌, vol.119-E, no.8, pp.401-404, 1999.

[13] H. Kurino, K.W. Lee, T. Nakamura, K. Sakuma, K.T. Park, N. Miyakawa, H. Shimazutsu, K.Y. Kim, K. Inamura and M. Koyanagi: "Intelligent Image Sensor Chip with Three Dimensional Structure," IEEE IEDM99, pp.879-882, 1999.

[14] K. Hirata, H. Niitsuma and M. Esashi: "Fabrication and Characterization of a Downhole Micro Accelerometer Using a FabryPerot Interferometer," The Fifth Well Logging Symposium of Japan, pp.1-8, 1999.

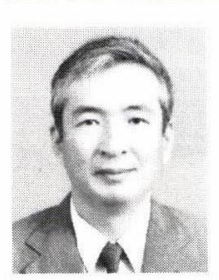

\section{江刺正喜 (Masayoshi Esashi)}

1976 年東北大学大学院博士課程（電子工学専 攻) 修了. 同年より東北大学工学部助手, 1981 年助教授, 1990 年より教授となり現在末来科 学技術共同研究センター教授に至る。半導体 センサ, マイクロマシニングによる集積化シ ステム, 省エネルギー・省資源工学の研究に 従事. 電子通信学会業績賞 (1980 年), 日本 IBM 科学賞 (1993 年) 他, 工学博士, 電気学会他の会員. 